\title{
CORRESPONDENCE
}

\section{Imperial echoes}

SIR - Your note on the establishment of Imperial College's Centre for Biotechnology (Nature 24 June, p.617) has caught the sentiment of the occasion, but lacks one or two points of detail.

Imperial Biotechnology Ltd (IBL) is jointly owned by Imperial College ( 35 per cent), TDC Developments Ltd (35 per cent) and its own staff, who hold the balance. The fermentation pilot plant will be managed by IBL, which will expand the business of development and pilot scale manufacture of specialized biological products. The company and the college are fully committed to maintain and expand the current college teaching programme. They have made a teaching agreement for the provision of adequate pilot plant and fermentation facilities for the college's programme of work. Like any other customer, the college may buy additional resources for research purposes from the company above the agreed level.

Resources that were absorbed by the noncommercial pilot plant operation may now be released for academic purposes; the college is applying part of them to the two lecturer posts shortly to be advertised (the Leverhulme chair is financially self-contained). The lecturers' positions will not therefore be so precarious as the comment ". . . salaries will be met by the fees earned from contracts with outside bodies" implies. They will be normally established posts.

The Centre for Biotechnology sees contract work as a major factor in the development of its research programmes - biotechnology is nothing if not an applied discipline. However, a substantial proportion of the investment in the centre must come from Imperial College's own efforts - unless the college clearly demonstrates its commitment to the subject, the centre will lack the credibility it needs amongst its potential customers.

Imperial College has found what it believes to be a workable combination of commercial risk and academic purposes that suits its own particular circumstances. It is firmly committed to producing the people and the products needed by the biotechnology industry by these means.

Centre for Biotechnology,

Imperial College of Science and Technology, London $S W 7, U K$

\section{Meltdown risks}

SiR - Robert J. Yaes has overstated the hazard of a major nuclear accident by two orders of magnitude in his letter of 24 June (Nature, p.622). Not even a meltdown in midtown Manhattan could produce the "several million" deaths he envisions. The number of fatalities from a "maximum credible" accident, which the US Nuclear Regulatory Commission has estimated would occur once in 100,000 meltdowns, is put at 45,000 . This is comparable to the toll that might be expected from such "conventional" hazards as oil and gas explosions, and onefourth the number of deaths that could occur if a certain major dam in the Southern California earthquake fault zone should break.

\section{Not by mirrors}

SIR - In News and Views of 28 January (p.277), Jared Diamond discussed the occurrence of migratory birds in places outside their normal geographic range (vagrants) ${ }^{1}$. Such vagrancy has been noted in many parts of the world and a variety of hypotheses have been put forward to account for it. By discussing only the ingenious "mirror-image misorientation" hypothesis of DeSante ${ }^{2}$, Diamond erroneously implied not only that it is the proven mechanism underlying the occurrence of vagrant warblers in California but also that it can account for vagrancy on a worldwide basis.

Based on the hypothesis that some individuals in a population of migrants make mirror-image orientational errors (such as heading SW instead of SE in autumn), DeSante predicted the relative frequency with which various species should occur. The pattern of records supported the hypothesis. The blackpoll warbler (Dendroica striata), which migrates towards the SE over North America in the fall, is the most numerous vagrant on the California coast. $A$ priori, one would expect warblers captured off coastal California to show SW hopping in an orientation cage. DeSante tested blackpolls captured on the Farallon Islands off California. Unfortunately, almost none of the birds oriented toward SW; most mean directions were toward NE or NW. The results could be explained only by the a posteriori hypothesis that the birds have four preferred directions: the normal SE heading, the SW mirror-image, and the reverse of these two. The data, therefore, do not provide strong, clear support for the original hypothesis.

The mirror-image misorientation hypothesis is important and deserves further testing. It is premature, however, to regard it as proven or to extend it to other areas of the world. There are data to suggest that weather patterns, especially wind, may play a large role in bringing vagrants to California and other areas ${ }^{3}$. Recently, a strong association between the arrival of vagrants and particular wind patterns has been demonstrated in Great Britain. Interestingly, the blackpoll warbler is the most numerous warbler vagrant from North America, a fact very difficult to account for by mirror-image misorientation ${ }^{4}$.

KenNeTh P. Able SCOTT B. TERRILL JEFFREY D. CHERRY

Department of Biological Sciences, State University of New York, USA

\footnotetext{
. Diamond, J.M. Nature 295, 277-278 (1982) . DeSante, D.F. thesis, Stanford Univ. (1973).

. Able, K.P. in Animal Migration, Orientation, and Navigation (Academic, New York, 1980). 4. Elkins, N. Br. Birds 72, 417 (1979).
}

\section{Prions have feathers}

SIR - In News and Views on 13 May ${ }^{1}$, R.H. Kimberlin discusses S.B. Prusiner's recent suggestion in Science that scrapie is caused by some new sort of proteinaceous infective particle or "prion", to use the acronymic neologism suggested by Prusiner ${ }^{2}$. However, there can be no doubt that prions exist. They contain lots of nucleic acid, packaged in a wonderful variety of proteins. One of the more striking of the proteins is keratin, arranged in a complex structure, the feather, that enables the prions to maintain their temperatures well above ambient and to flutter above the southern oceans.

Today the prions are placed in the genus Pachyptila. Their vernacular name stems from the generic name given by Lacépéde, after the serrated edge to the birds' mandibles ( $\iota \iota \omega \nu$, a saw). It was in use as an English name among ornithologists in the last century ${ }^{3}$ and is given in the Oxford English Dictionary.

Perhaps in this case there is little chance of confusing the old and new meanings of the word. But precision and unambiguity are important in science - even if they are not in Science, whose editors do not wish to point out this unfortunate homonymy to their readers. I hope you will be more concerned and that Pachyptila will in future be the only prion to appear in Nature, whether or not "proteinaceous infective particles" occur in nature.

J.J.D. GREENWOOD

Department of Biochemistry,

University of Dundee, UK

1. Kimberlin, R.H. Nature 297, 107-108 (1982).

2. Prusiner, S.B. Science 216, 136 (1982)

3. Newton, A. A Dictionary of Birds (1896)

\section{The parasitic balance}

SIR - I am sure Professor Cox does not need me or anyone else to defend him, but Dr Palmieri's letter (Nature 15 July, p.220) does not seem to take account of the fact that Cox's original report (Nature 4 March, p.10) was an account of a symposium specifically devoted to diseases caused by parasites. Aside from this, of course, Palmieri's contention is true most parasites are in balance, albeit maybe a delicate balance, with their hosts.

Notable examples are found amongst parasites of wild animals, in this country and elsewhere. Flagellates and sporozoans are almost ubiquitous amongst the wild vertebrates of this country, but direct pathogenic effects of their presence are rare. This does not necessarily mean, however, that such infections are not subtly harmful in conditions of unusual stress, or by virtue of immunodepressive effects. A deeper understanding of factors involved in maintaining the balance might help explain why it sometimes breaks down, with devastating effects among the host population, as exemplified by recent epidemic sleeping sickness (human trypanosomiasis) in parts of Africa.

I.R. BAKER

The Institute of Terrestrial Ecology, Cambridge, UK

\section{Philosopher in gaol}

SIR - I have received first-hand information concerning Professor Lessek Novak from the University in Poznan, a distinguished philosopher in Poland's strong tradition of logicians. He has been confined for seven months, held in a prison without daylight and infested with bugs. Professor Novak took part in the postgraduate courses at the InterUniversity Centre in Dubrovnik and has been very active in international collaboration in science. His confinement is a grave violation of human rights, particularly that of freedom of thought. I appeal to the scientific community to do everything possible to bring about his liberation. IVANSUPEK Institute for History and Philosophy of Science, Zagreb, Yugoslavia 